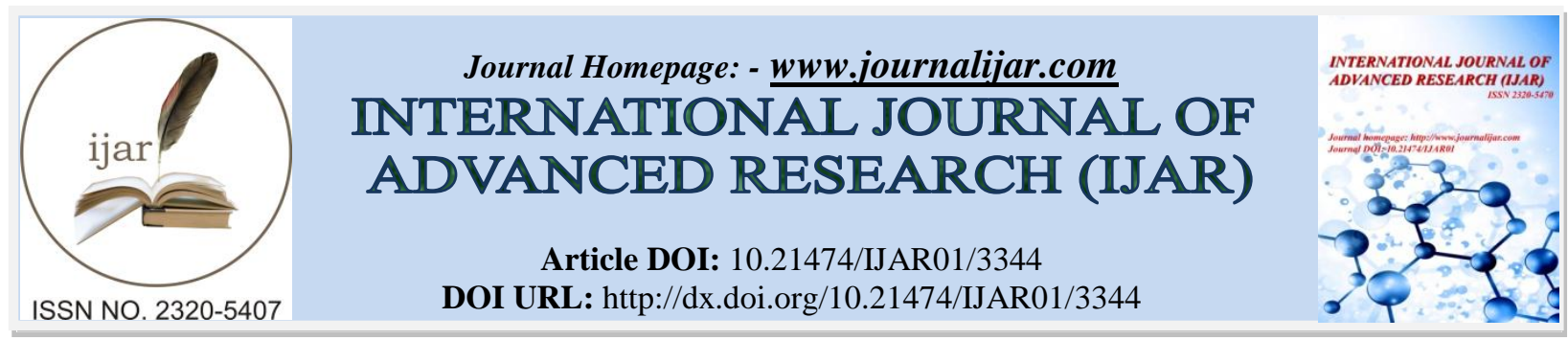

RESEARCH ARTICLE

\title{
HEAVY METAL TOLERANCE BY Vetiveria Zizanioides (L.) NASH FROM SOLID WASTE AT AMBERNATH DUMPSITE AND RELATED HEALTH EFFECTS.
}

Sonal. P. Tawde ${ }^{1}$ and Satish A. Bhalerao ${ }^{2}$.

1. Department of Environmental Sciences, Birla College, College Road, Kalyan West.

2. Environmental Sciences Research Laboratory, Department of Botany, Wilson College, Mumbai.

\section{Manuscript Info}

Manuscript History

Received: 26 December 2016

Final Accepted: 18 January 2017

Published: February 2017

Key words:-

Phytoremediation, Vetiver, Indices, Uptake, Accumulation

\section{Abstract}

Urbanization and industrialization has given rise to large quantities of solid wastes. Due to resource crunch or inefficient infrastructure, not all of this waste gets collected and transported to the dumpsites. Phytoremediation is energy efficient, aesthetically pleasing method of remediating sites with low-to-moderate levels of contamination and it reduces the mobility of heavy metals and prevents migration to the groundwater and soil of the dumpsite. The present study involves study of uptake of heavy metals by the plant Vetiveria zizanioides (L.) Nash., and estimation of the Phytoremediation Indices of Transfer factor, Bioconcentration factor, Translocation factor and Translocation Index. Hence in the present study, an attempt has been made to analyze the uptake of metals present in the dumpsite wastes from Ambernath dumpsite (Maharashtra State), which are amended with garden (Control) soil on Vetiver. There is an increasing trend of uptake and accumulation of Cadmium (Cd), Chromium (Cr) and Zinc ( $\mathrm{Zn})$, with increasing ratio of control soil to dumpsite soil $(\mathrm{Cr}>\mathrm{Zn}>\mathrm{Cd})$. The low values of Transfer factor, Bioconcentration factor and translocation factors $(<1)$, indicates that Vetiver is a hypoaccumulator for all selected heavy metals. The higher transfer factor values when compared to the lower translocation factor values indicates that the accumulation of metals is in the order of root>leaves.

Copy Right, IJAR, 2017,. All rights reserved.

\section{Introduction:-}

Open dumpsite approach as solid waste disposal method is a primitive stage of solid waste management in many parts of the world. It is one of the most poorly rendered services by municipal authorities in developing countries as the systems applied are unscientific, outdated and in- efficient. Solid waste generation is a continuously growing problem at global, regional and local levels (Rode, 2011). With increase in the global population and the rising demand for food and other essentials, there has been a rise in the amount of waste being generated daily by each house- hold. This waste is ultimately thrown into municipal disposal sites and due to poor and ineffective management, the dumpsites turn to sources of environmental and health hazards to people living in the vicinity of such dumps. The present study involves study of uptake of heavy metals by Vetiveria zizanioides (L.) Nash., commonly known as Vetiver. These plants may are capable of accumulating many of these metals due to their quick growth, deep roots and tall aerial organs (Manios et.al, 2003). An attempt has been made to analyze the uptake of metals present in the dumpsite wastes from Ambernath dumpsite in Thane District, which are amended with garden 
(Control) soil on Vetiver. The three metals Cadmium, Chromium and Zinc are studied for their initial concentrations in the dumpsite soil. Vetiveria zizanioides (L.) Nash was then exposed to these soils. Pollutants especially metals deposited on land usually enter the human body through the medium of contaminated crops, animals, food products, or water. Also, the dumpsite has smelly and unhealthy conditions. These conditions are worse in the summer because of extreme temperatures, which speed up the rate of bacterial action on biodegradable organic material. Disposal sites can also create health hazards for the neighborhood. In a number of health surveys a wide range of health problems, including respiratory systems, irritation of the skin, eyes and nose, gastrointestinal problems, psychological disorders, and allergies, have been discovered.

\section{Materials and Methods:-}

The Sampling of solid waste is done by 'Cone and Quarter' method at the site from different locations of the dumpsite. The soil is then air dried of from solid waste. The soil is then sieved through $0.5 \mathrm{~mm}$ sieve. 3 replications of one month old vetiver plant is made and acclimatized for one month. Pruning is done to $20 \mathrm{~cm}$ and $10 \mathrm{~cm}$ slips respectively. The different ratios are prepared as Control soil: Landfill waste soil (C:L), i.e.1:1, 1:2, 1:3 and 1:4 respectively, along with $100 \%$ each of garden and landfill waste soil respectively. Metal Analysis is performed by standard procedures prescribed (APHA, 1998; Behera 2006; Maiti 2003).

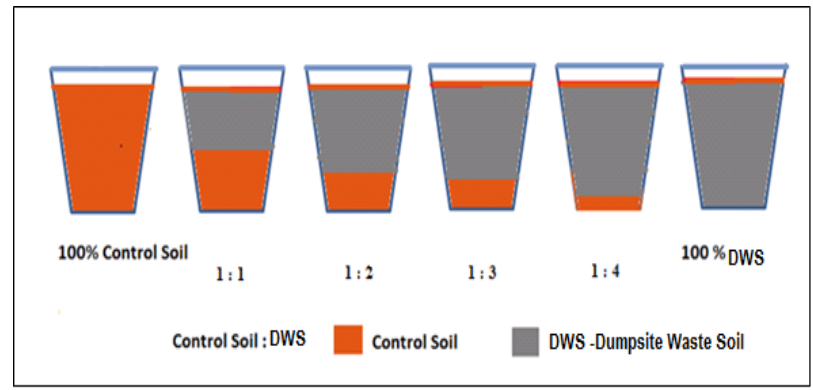

Fig 1:-Diagrammatic representation of pot experiments for selected ratios of dumpsite waste amended soils.

Following factors are estimated:

\section{i. $\quad$ Transfer Factor $=$}

Concentration of metal in root/leaves

Concentration of metal in soil

ii. Bio Conc. Factor =

Conc. of metal in plant tissue (roots+leaves)

Concentration of metal in soil

\section{iii. Translocation Factor $=$}

Metal concentration in leaves

Metal concentration in root

iv. Translocation Index =

Metal conc. in leaves $(\mathrm{mg} / \mathrm{gm}) \times \mathbf{1 0 0}$

Metal conc. in roots $(\mathrm{mg} / \mathrm{gm})$ 
Observations and Results:-

Table 1:- Phytoremediation ability of Vetiver at different ratios of control soil: landfill waste soil in terms of Cadmium $(\mathrm{Cd})$.

\begin{tabular}{|c|c|c|c|c|c|c|c|}
\hline Trtmnt & Replicate & $\begin{array}{l}\text { Cd Conc. in } \\
\text { Roots+Leaves* } \\
\text { mg/Kg }\end{array}$ & $\begin{array}{l}\text { Transfer } \\
\text { Factor Root }\end{array}$ & $\begin{array}{l}\text { Transfer } \\
\text { Factor } \\
\text { Leaves }\end{array}$ & $\overline{\text { BCF }}$ & $\begin{array}{ll}\text { TF } & \text { (leaf } \\
\text { /root) }\end{array}$ & TI \\
\hline \multirow{3}{*}{$\begin{array}{l}\text { C:L } \\
1: 1\end{array}$} & R1 & 19.32 & 1.15 & 0.97 & 2.12 & 0.84 & 84 \\
\hline & R2 & 19.92 & 1.08 & 0.86 & 1.94 & 0.79 & 79.46 \\
\hline & R3 & 18.51 & 0.8 & 0.73 & 1.53 & 0.91 & 91.02 \\
\hline \multicolumn{2}{|l|}{ Mean \pm SD } & $19.25 \pm 0.71$ & $1.01 \pm 0.19$ & $\begin{array}{ll}0.85 & \pm \\
0.12 & \end{array}$ & $\begin{array}{l}1.86 \\
\pm \\
0.30\end{array}$ & $0.85 \pm 0.06$ & $\begin{array}{l}84.82 \\
\pm \\
5.82\end{array}$ \\
\hline \multirow{3}{*}{$\begin{array}{l}\text { C:L } \\
1: 2\end{array}$} & R1 & 24.36 & 0.71 & 0.54 & 1.25 & 0.75 & 75.13 \\
\hline & $\mathrm{R} 2$ & 23.44 & 0.7 & 0.46 & 1.11 & 0.7 & 70.1 \\
\hline & R3 & 23.62 & 0.68 & 0.48 & 1.15 & 0.7 & 70.05 \\
\hline \multicolumn{2}{|l|}{ Mean \pm SD } & $23.81 \pm 0.49$ & $0.7 \pm 0.70$ & $\begin{array}{ll}0.49 & \pm \\
0.04 & \end{array}$ & $\begin{array}{l}1.17 \\
\pm \\
0.07\end{array}$ & $0.72 \pm 0.02$ & $\begin{array}{l}71.76 \\
\pm \\
2.92\end{array}$ \\
\hline \multirow{3}{*}{$\begin{array}{l}\text { C:L } \\
1: 3\end{array}$} & $\mathrm{R} 1$ & 26.04 & 0.54 & 0.39 & 0.93 & 0.71 & 70.64 \\
\hline & R2 & 26.04 & 0.57 & 0.41 & 0.98 & 0.71 & 71.77 \\
\hline & R3 & 26.61 & 0.53 & 0.4 & 0.93 & 0.74 & 74.72 \\
\hline \multicolumn{2}{|l|}{ Mean \pm SD } & $26.23 \pm 0.33$ & $0.55 \pm 0.55$ & $0.4 \pm 0.01$ & $\begin{array}{l}0.95 \\
\pm \\
0.02\end{array}$ & $0.72 \pm 0.72$ & $\begin{array}{l}72.28 \\
\pm \\
2.11\end{array}$ \\
\hline \multirow{3}{*}{$\begin{array}{l}\mathrm{C}: \mathrm{L} \\
1: 4\end{array}$} & R1 & 30.03 & 0.52 & 0.44 & 0.95 & 0.84 & 84.46 \\
\hline & R2 & 29.64 & 0.55 & 0.46 & 1.01 & 0.84 & 84.21 \\
\hline & R3 & 29.77 & 0.52 & 0.44 & 0.95 & 0.84 & 84.22 \\
\hline \multicolumn{2}{|l|}{ Mean \pm SD } & $29.81 \pm 0.20$ & $0.53 \pm 0.53$ & $\begin{array}{ll}0.45 & \pm \\
0.01 & \end{array}$ & $\begin{array}{l}0.97 \\
\pm \\
\mathbf{0 . 0 3}\end{array}$ & $0.84 \pm 0$ & $\begin{array}{l}84.3 \\
\pm \\
0.14\end{array}$ \\
\hline \multirow[t]{3}{*}{$100 \%$ LWS } & R1 & 49.71 & 0.56 & 0.4 & 0.96 & 0.71 & 71.47 \\
\hline & $\mathrm{R} 2$ & 49.84 & 0.93 & 0.67 & 1.6 & 0.72 & 71.57 \\
\hline & R3 & 49.86 & 0.4 & 0.29 & 0.69 & 0.71 & 71.4 \\
\hline \multicolumn{2}{|l|}{ Mean \pm SD } & $49.8 \pm 0.08$ & $0.63 \pm 0.63$ & $0.45 \pm 0.2$ & $\begin{array}{l}1.08 \\
\pm 0.5\end{array}$ & $0.71 \pm .005$ & $\begin{array}{l}71.48 \\
\pm \\
0.09\end{array}$ \\
\hline
\end{tabular}

Table 2:- Phytoremediation ability of Vetiver at different ratios of control soil: landfill waste soil in terms of Chromium (Cr)

\begin{tabular}{|c|c|c|c|c|c|c|c|}
\hline Treatment & Replicates & $\begin{array}{l}\mathrm{Cr} \text { Conc. in } \\
\text { Roots+Leaves* } \\
\mathrm{mg} / \mathrm{Kg}\end{array}$ & $\begin{array}{l}\text { Transfer } \\
\text { Factor Root }\end{array}$ & $\begin{array}{l}\text { Transfer } \\
\text { Factor } \\
\text { Leaves }\end{array}$ & BCF & $\begin{array}{l}\text { TF (leaf } \\
\text { /root) }\end{array}$ & TI \\
\hline \multirow{3}{*}{$\begin{array}{l}\text { C:L } \\
1: 1\end{array}$} & R1 & 75.99 & 0.13 & 0.13 & 0.63 & 0.25 & 25.13 \\
\hline & R2 & 76.01 & 0.12 & 0.12 & 0.62 & 0.25 & 25.08 \\
\hline & R3 & 76.03 & 0.13 & 0.13 & 0.63 & 0.25 & 25.19 \\
\hline \multicolumn{2}{|l|}{ Mean \pm SD } & $76.01 \pm 0.02$ & $0.13 \pm 0.005$ & $\begin{array}{ll}0.13 & \pm \\
0.005 & \\
\end{array}$ & $\begin{array}{l}0.63 \pm \\
0.005\end{array}$ & $0.25 \pm 0$ & $\begin{array}{l}25.13 \pm \\
0.06\end{array}$ \\
\hline \multirow{3}{*}{$\begin{array}{l}\mathrm{C}: \mathrm{L} \\
1: 2\end{array}$} & $\mathrm{R} 1$ & 105.67 & 0.35 & 0.12 & 0.47 & 0.34 & 34.12 \\
\hline & R2 & 105.63 & 0.35 & 0.12 & 0.47 & 0.34 & 34.1 \\
\hline & R3 & 105.66 & 0.35 & 0.12 & 0.47 & 0.34 & 34.15 \\
\hline \multicolumn{2}{|l|}{ Mean \pm SD } & $105.65 \pm 0.02$ & $0.35 \pm 0$ & $0.12 \pm 0$ & $\begin{array}{l}0.47 \pm \\
0\end{array}$ & $0.34 \pm 0$ & $\begin{array}{l}\text { 34.12 } \pm \\
\mathbf{0 . 0 3}\end{array}$ \\
\hline \multirow{2}{*}{$\begin{array}{l}\mathrm{C}: \mathrm{L} \\
1: 3 \\
\end{array}$} & $\mathrm{R} 1$ & 133.35 & 0.29 & 0.17 & 0.46 & 0.57 & 56.81 \\
\hline & $\mathrm{R} 2$ & 133.48 & 0.3 & 0.17 & 0.48 & 0.57 & 56.8 \\
\hline
\end{tabular}




\begin{tabular}{|c|c|c|c|c|c|c|c|}
\hline & R3 & 133.44 & 0.28 & 0.16 & 0.44 & 0.57 & 56.75 \\
\hline \multicolumn{2}{|l|}{ Mean \pm SD } & $133.42 \pm 0.06$ & $0.29 \pm 0.01$ & $\begin{array}{ll}0.17 & \pm \\
0.005 & \end{array}$ & $\begin{array}{l}0.46 \pm \\
0.02\end{array}$ & $0.57 \pm 0$ & $\begin{array}{l}56.79 \pm \\
0.03\end{array}$ \\
\hline \multirow{3}{*}{$\begin{array}{l}\text { C:L } \\
1: 4\end{array}$} & $\mathrm{R} 1$ & 170.43 & 0.3 & 0.21 & 0.51 & 0.69 & 69.25 \\
\hline & R2 & 173.47 & 0.31 & 0.21 & 0.52 & 0.67 & 67.21 \\
\hline & R3 & 174.2 & 0.31 & 0.21 & 0.52 & 0.67 & 66.63 \\
\hline \multicolumn{2}{|l|}{ Mean \pm SD } & $172.7 \pm 1.99$ & $0.31 \pm 0.005$ & $0.21 \pm 0$ & $\begin{array}{l}0.52 \\
\pm 0.005 \\
\end{array}$ & $\begin{array}{ll}0.68 & \pm \\
0.01 & \\
\end{array}$ & $\begin{array}{ll}67.7 & \pm \\
1.38 & \\
\end{array}$ \\
\hline \multirow[t]{3}{*}{$100 \%$ LWS } & R1 & 244.39 & 0.25 & 0.15 & 0.39 & 0.59 & 58.93 \\
\hline & $\mathrm{R} 2$ & 244.3 & 0.26 & 0.16 & 0.39 & 0.59 & 58.86 \\
\hline & R3 & 244.27 & 0.3 & 0.18 & 0.49 & 0.59 & 58.91 \\
\hline Mean \pm SD & & $244.32 \pm 0.06$ & $0.27 \pm 0.015$ & $\begin{array}{l}0.16 \\
0.02\end{array}$ & $\begin{array}{l}0.42 \pm \\
0.06\end{array}$ & $0.59 \pm 0$ & $\begin{array}{ll}\mathbf{5 8 . 9} & \pm \\
\mathbf{0 . 0 4} & \end{array}$ \\
\hline
\end{tabular}

Table 3:- Phytoremediation ability of Vetiver at different ratios of control soil: landfill waste soil in terms of Zinc (Zn)

\begin{tabular}{|c|c|c|c|c|c|c|c|}
\hline Treatment & Replicates & $\begin{array}{l}\text { Zn Conc. in } \\
\text { Roots+Leaves* } \\
\text { mg/Kg }\end{array}$ & $\begin{array}{l}\text { Transfer } \\
\text { Factor } \\
\text { Root }\end{array}$ & $\begin{array}{l}\text { Transfer } \\
\text { Factor } \\
\text { Leaves }\end{array}$ & BCF & $\begin{array}{l}\text { TF } \\
\text { (leaf } \\
\text { /root) }\end{array}$ & TI \\
\hline \multirow{3}{*}{$\begin{array}{l}\text { C:L } \\
1: 1\end{array}$} & R1 & 74.48 & 0.6 & 0.11 & 0.72 & 0.19 & 18.52 \\
\hline & R2 & 73.98 & 0.6 & 0.11 & 0.71 & 0.19 & 18.63 \\
\hline & R3 & 73.49 & 0.6 & 0.11 & 0.71 & 0.19 & 19.17 \\
\hline \multicolumn{2}{|l|}{ Mean \pm SD } & $73.98 \pm 0.50$ & $0.6 \pm 0.0$ & $0.11 \pm 0.0$ & $\begin{array}{l}0.71 \\
\pm \\
0.006\end{array}$ & $\begin{array}{ll}\text { 0.19 } & \pm \\
0.0 & \end{array}$ & $\begin{array}{l}18.77 \pm \\
0.35\end{array}$ \\
\hline \multirow{3}{*}{$\begin{array}{l}\mathrm{C}: \mathrm{L} \\
1: 2\end{array}$} & R1 & 91.94 & 0.24 & 0.05 & 0.29 & 0.21 & 21.39 \\
\hline & $\mathrm{R} 2$ & 91.53 & 0.22 & 0.05 & 0.27 & 0.21 & 21.39 \\
\hline & R3 & 92.17 & 0.23 & 0.05 & 0.28 & 0.21 & 21.37 \\
\hline \multicolumn{2}{|l|}{ Mean \pm SD } & $91.88 \pm 0.32$ & $0.23 \pm 0.01$ & $0.05 \pm 0.0$ & $\begin{array}{l}0.28 \\
\pm \\
0.01\end{array}$ & $\begin{array}{ll}0.21 & \pm \\
0.0 & \end{array}$ & $\begin{array}{ll}21.38 & \pm \\
0.01 & \end{array}$ \\
\hline \multirow{3}{*}{$\begin{array}{l}\mathrm{C}: \mathrm{L} \\
1: 3\end{array}$} & R1 & 111.39 & 0.18 & 0.05 & 0.23 & 0.26 & 25.75 \\
\hline & R2 & 111.46 & 0.19 & 0.05 & 0.24 & 0.26 & 26.03 \\
\hline & R3 & 111.52 & 0.18 & 0.05 & 0.23 & 0.26 & 26.08 \\
\hline \multicolumn{2}{|l|}{ Mean \pm SD } & $111.46 \pm 0.07$ & $\begin{array}{ll}0.18 & \pm \\
0.006 & \end{array}$ & $0.05 \pm 0.0$ & $\begin{array}{l}0.23 \\
\pm \\
0.006\end{array}$ & $\begin{array}{ll}0.26 & \pm \\
0.0 & \end{array}$ & $\begin{array}{l}25.95 \quad \pm \\
0.18\end{array}$ \\
\hline \multirow{3}{*}{$\begin{array}{l}\text { C:L } \\
1: 4\end{array}$} & R1 & 130.61 & 0.17 & 0.05 & 0.23 & 0.29 & 29.46 \\
\hline & R2 & 130.47 & 0.18 & 0.05 & 0.23 & 0.29 & 29.49 \\
\hline & R3 & 130.03 & 0.17 & 0.05 & 0.22 & 0.3 & 29.7 \\
\hline \multicolumn{2}{|l|}{ Mean \pm SD } & $130.37 \pm 0.30$ & $\begin{array}{ll}0.17 & \pm \\
0.006 & \end{array}$ & $0.05 \pm 0.0$ & $\begin{array}{l}0.23 \\
\pm \\
0.006\end{array}$ & $\begin{array}{l}0.29 \pm \\
0.006\end{array}$ & $\begin{array}{ll}29.55 & \pm \\
0.13 & \end{array}$ \\
\hline \multirow[t]{3}{*}{$100 \%$ LWS } & $\mathrm{R} 1$ & 146.37 & 0.11 & 0.04 & 0.16 & 0.4 & 36.63 \\
\hline & $\mathrm{R} 2$ & 145.87 & 0.16 & 0.06 & 0.21 & 0.37 & 36.99 \\
\hline & $\mathrm{R} 3$ & 146.71 & 0.13 & 0.05 & 0.18 & 0.37 & 36.6 \\
\hline \multicolumn{2}{|l|}{ Mean \pm SD } & $146.32 \pm 0.42$ & $0.13 \pm 0.02$ & $0.05 \pm 0.0$ & $\begin{array}{l}0.18 \\
\pm \\
0.03\end{array}$ & $\begin{array}{l}\text { 0.38 } \\
\text { 0.02 }\end{array}$ & $\begin{array}{l}35.74 \quad \pm \\
0.21\end{array}$ \\
\hline
\end{tabular}




\section{List Of Figures}

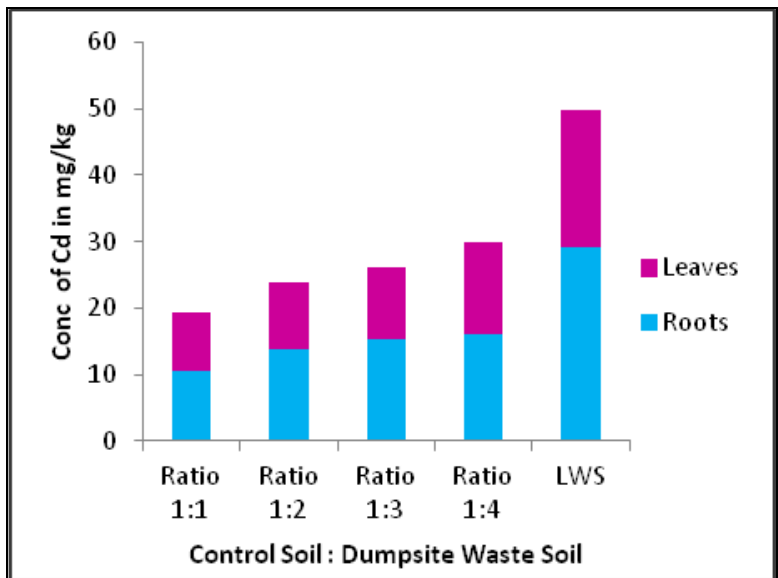

Fig 2:- Uptake of Cadmium (Cd) in different ratios by Vetiver in roots and leaves

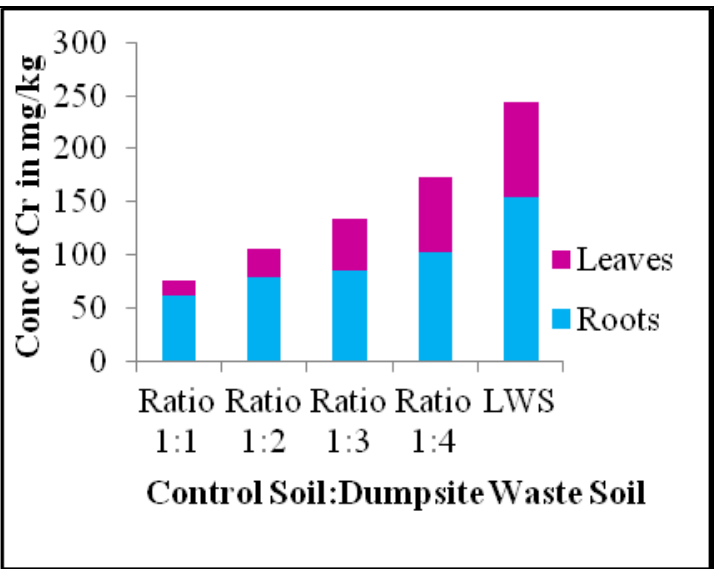

Fig 3:- Uptake of Chromium (Cr) in different ratios by Vetiver in roots and leaves

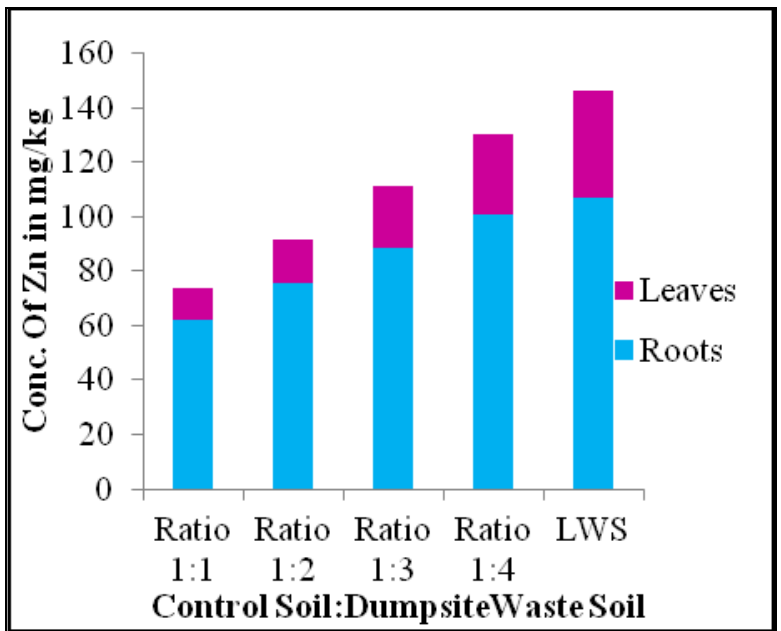

Fig 4:- Uptake of Zinc (Zn) in different ratios by Vetiver in roots and leaves 


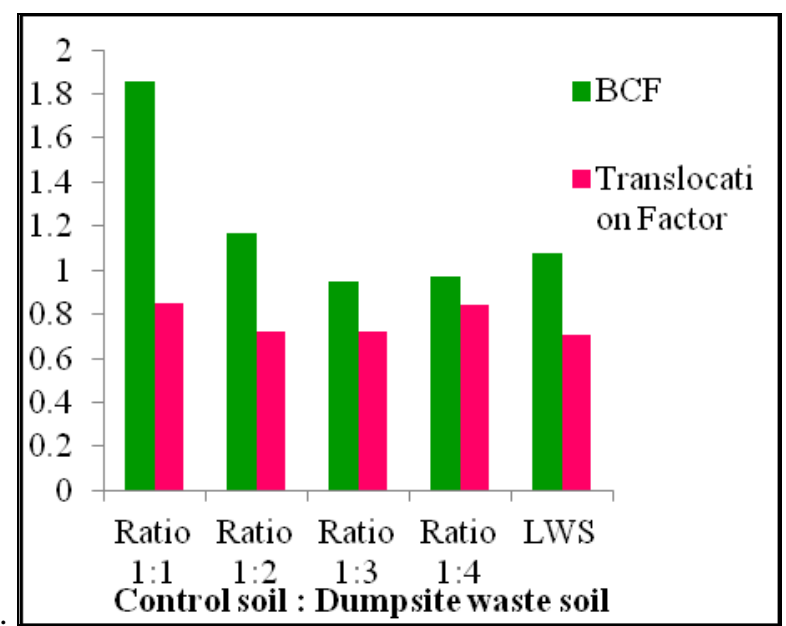

Fig 5:- Comparison of BCF and translocation factor of Cadmium $(\mathrm{Cd})$ by Vetiver

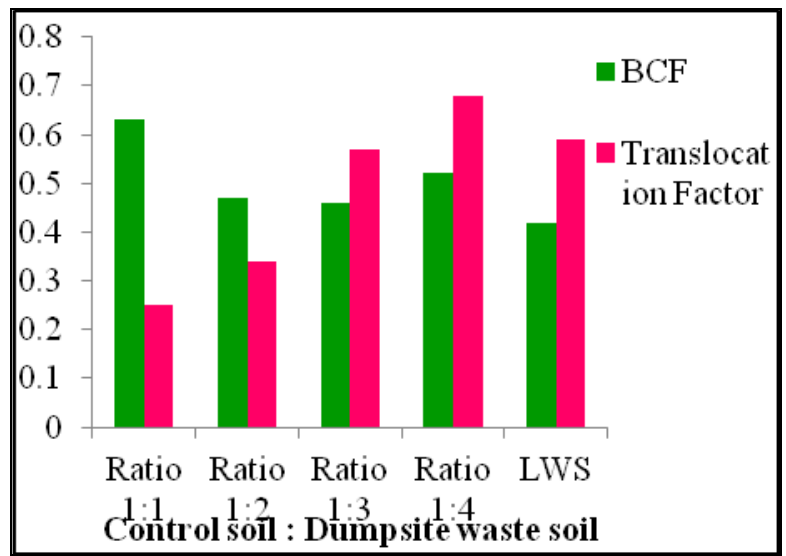

Fig 6:- Comparison of BCF and translocation factor of Chromium (Cr) by Vetiver

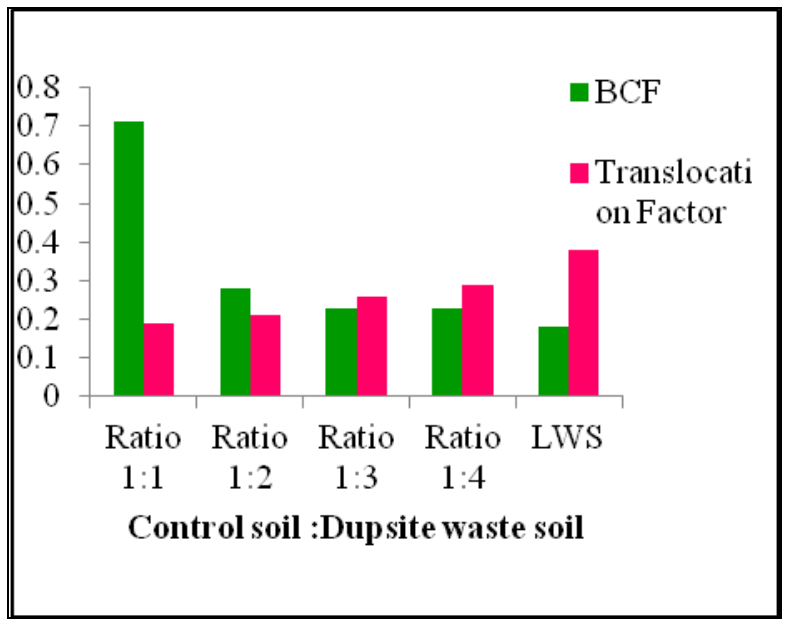

Fig 7:-Comparison of BCF and translocation factor of Zinc (Zn) by Vetiver

Discussion:-

Effects of Dumpsite:-

The negative effects are most commonly placed into two distinct categories: atmospheric effects and hydrological effects. 


\section{Atmospheric Effects:-}

According to the EPA, the methane produced by the rotting organic matter in unmanaged landfills is 20 times more effective than carbon dioxide at trapping heat from the sun. Not only does methane get produced by the various forms of rotting organic matter that find their way into landfills, but household cleaning chemicals often make their way here as well. The mixture of chemicals like bleach and ammonia in landfills can produce toxic gases that can significantly impact the quality of air in the vicinity of the landfill.

\section{Hydrological Effects:-}

Landfills also create a toxic soup of industrial and home-cleaning chemicals. People throw away everything from industrial solvents to household cleaners in landfills, and these chemicals accumulate and mix over time. A more immediate concern is for the welfare of the wildlife that comes into contact with these chemicals, and it is not uncommon for animals to suffer inconceivably painful deaths resulting from chemical contamination ( $\mathrm{Zu}$ et.al, 2005). The three most important are toxins, leachate and greenhouse gases.

\section{Toxins:-}

Many materials that end up as waste contain toxic substances. Over time, these toxins leach into our soil and groundwater, and become environmental hazards for years. Electronic waste is a good example. Waste such as televisions, computers and other electronic appliances contain a long list of hazardous substances, including mercury, arsenic, cadmium, PVC, solvents, acids and lead. It's called Methylmercury and it is a highly toxic agent. In nature, methylmercury forms in aquatic systems when anaerobic organisms (organisms that don't need oxygen) feed on it. Unfortunately, landfills often imitate the same conditions. The result can be concentrations of methylmercury in our environment up to 100 times the normal levels (as was the case with a landfill in Florida). That's pretty toxic. Methylmercury is a bioaccumulant, which basically means it builds up in our food chain, and it's most commonly ingested by eating fish. Methylmercury is so dangerous; it can even impede the development of a child's nervous system. E-waste is a very toxic problem. A mixture of different chemicals goes into making electronics, and these leach into our soil and groundwater as the products degrade. Some of these chemicals are lead brominated flame retardants, antimony oxide, cadmium and beryllium. They all end up in our environment and potentially affecting our public health.

\section{Leachate:-}

Leachate is the liquid formed when waste breaks down in the landfill and water filters through that waste. This liquid is highly toxic and can pollute the land, ground water and water ways.

\section{Greenhouse gas:-}

When organic material such as food scraps and green waste is put in landfill, it is generally compacted down and covered. This removes the oxygen and causes it to break down in an anaerobic process. Eventually this releases methane, a greenhouse gas that is 21 times more potent than carbon dioxide. The implications for global warming and climate change are enormous. Methane is also a flammable gas that can become dangerous if allowed to build up in concentration. Composting your food scraps and green waste in a compost bin eliminates many of these problems.

\section{Health Effects of Dumpsite:-}

A few studies that have attempted to measure certain chemicals in blood and urine of populations near waste sites have generally not found increased levels of volatile organic compounds (VOCs) (Hanar et al. 1996) mercury (Reif et al. 1993), or PCBs (Stehr et al. 1998). Landfill sites may be a source of airborne chemical contamination via the off-site migration of gases and via particles and chemicals adhered to dust, especially during the period of active operation of the site. Very little is known about the likelihood of air exposure from landfill sites through landfill gases or dust. At some of the sites described below, low levels of volatile organic chemicals have been detected in indoor air of homes near landfill sites (Clark 1982, Goldman 1985) in outdoor air in areas surrounding sites (Deloraine 1995, Zmirou 1994) or in on-site landfill gas.

\section{Conclusions:-}

The tolerance of Vetiver to the selected three heavy metals at various concentrations in control soil and in landfill waste amended soils, reveals the survival potential at high toxic heavy metal range.

Vetiver accumulates large range of selected heavy metals in roots with low translocation to leaves. The order of metal uptake is roots>leaves. 
The risk of biomagnification of the metals through the food chain can be reduced using vetiver system at the landfill sites as the Metal Removal Efficiency in the range of $70-88 \%, \mathrm{TF}<1$, and $\mathrm{BCF}<1$, thus indicating the reduction in metal toxicity of the soil at the site, by adoption of exclusion strategy and suitability of the plant for phytostabilization.

The important implications of these findings are when vetiver is used for the rehabilitation of landfill sites contaminated with high levels heavy metals namely, Cadmium, Chromium, and Zinc, its leaves can be safely grazed by animals or harvested for mulch as very little of these heavy metals are translocated to the leaves (Ghosh 2005).

Thus from the present study it can be concluded that Vetiveria zizanioides (L.) Nash, wing to its good metal removal efficiency from the landfill waste soils and uptake of metals, can be used as an ecotechnological tool to manage the problem of solid waste at landfill site.

Research into the health effects of landfill sites is relatively immature, and further research could improve our current understanding. Future studies of landfill sites would greatly benefit from a more interdisciplinary approach, drawing from the fields of landfill engineering, environmental sciences, toxicology, and epidemiology.

Johnson. B.L, et al, 1997, in a recent review of toxicological hazards of Superfund waste sites, conclude that although a large body of toxicological research is under way to assess the toxicity of chemicals commonly contaminating the environment surrounding waste sites, equally significant work is still to be done before these chemicals have adequate toxicity profiles that can be used by health and risk assessors.

\section{References:-}

1. APHA, AWWA \& WEF, $20^{\text {th }}$ Ed. Standard Methods for the examination of water and wastewater, American Public Health Association, Washington, D.C. (1998).

2. Behera, P.K. Soil and Solid Waste Analysis : A Laboratory Manual, Dominant Publishers, New Delhi, India. (2006).

3. Clark CS, Meyer CR, Gartside PS, Majeti VA, Specker B, Balistreri WF, Elia VJ. An environmental health survey of drinking water contamination by leachate from a pesticide waste dump in Hardeman County, Tennessee. Arch Environ Health 37:9-18 (1982).

4. Deloraine A, Zmirou D, Tillier C, Boucharlat A, Bouti H. Case-control assessment of the short-term health effects of an industrial toxic waste landfill. Environ Res 68:124-132 (1995).

5. Ghosh, M. \& Singh, S. PA comparative study of cadmium phytoextraction by accumulator and weed species. Environmental Pollution, 133, 365-371. . (2005)

6. Goldman LR, Paigen B, Magnant MM, Highland JH. Low birth weight, prematurity and birth defects in children living near the hazardous waste site, Love Canal. Haz Waste Haz Mat 2:209- 223 (1985).

7. Hamar GB, McGeehin MA, Phifer BL, Ashley DL. Volatile organic compound testing of a population living near a hazardous waste site. J Expo Anal Env Epidemiol 6:247-255 (1996).

8. Johnson BL, DeRosa CT. The toxicologic hazard of Superfund hazardous waste sites. Rev Environ Health 12:35-251 (1997).

9. Maiti, S.K. (2003). Handbook of Methods in Environmental Studies, ABD Publishers, Jaipur, India.

10. Manios, T, Stentiford, E. I. \& Millner, P. A. (2003). The effect of heavy metals accumulation on the chlorophyll concentration of Typha latifolia plants, growing in a substrate containing sewage sludge compost and watered with metaliferus water. Ecological Engineering, 20: 65-74.

11. Reif JS, Tsongas TA, Anger WK, Mitchell J, Metzger L, Keefe TJ, Tessari JD, Amler R. Two-stage evaluation of exposure to mercury and biomarkers of neurotoxicity at a hazardous waste site. J Toxicol Environ Health 40:413-422 (1993).

12. Rode. S. Public Private Partnership in Solid Waste Management in Municipal Corporations of Mumbai Metropolitan Region. MPRA Paper No. 34530, UTC. (2011).

13. Stehr-Green PA, Burse VW, Welty E. Human exposure to polychlorinated biphenyls at toxic waste sites: investigations in the United States. Arch Environ Health 43:420-424 (1988).

14. Zmirou D, Deloraine A, Saviuc P, Tillier C, Boucharlat A, Maury N. Short-term health effects of an industrial toxic waste landfill: a retrospective follow-up study in Montchanin, France. Arch Environ Health 49:228-238 (1994).

15. Zu, Y., Yuan, L., Jianjun, C., Haiyan, C., Li, Q. and Schvartz, C. Hyperaccumulation of Pb, Zn and Cd in herbaceous grown on lead-zinc mining area in Yunnan, China, Environ. Int. J., vol. 31, no. 5, pp, 755- 762. (2005). 